\title{
The Real Contours and Targets for the BRICS Monetary Partnership to Facilitate Trade and Investment
}

\author{
N. Khmelevskaya
}

\begin{abstract}
Natalia Khmelevskaya - Associate professor, Moscow State Institute of International Relations of Ministry of Foreign Affairs of Russia; 76 Vernadskogo av., 119454 Moscow, Russian Federation; E-mail: Khmelevskaya@ mgimo.ru
\end{abstract}

This article focuses on the evolution of monetary cooperation among BRICS members of Brazil, Russia, India, China and South Africa and on testing the bilateral trade and exchange rate indicators to target transaction costs as they drive export growth. The discussion starts with the formal arrangements to ensure the settlement of trade among the BRICS members in local currencies. Export similarity index (ESI) analysis of similarities between BRICS member's export structures reveals that during the period 2009-2013 benefits for the BRICS from shifts in export structure depended first on China's role in vertical trade integration and second on China as a growing source of demand for the BRICS economies. With regard to exchange rate indicators, the magnitude of the trade response to exchange rate deviations depends on the overall structure of exports. Then any BRICS currency devaluations that anticipate inflation are attributed to exchange rate discrepancies and associated with dumping. Hence their divergent effects on export - Russia's exports grew largely through mineral fuel, and Brazil has gained from its deepening trade relationships. Therefore transaction costs may be reduced via common trade settlement arrangements and trade facilitation. The article introduces ideas for designing BRICS payment and settlement mechanisms. One suggestion is to build a clearing union on the platform of the pool of BRICS conditional currency reserves similar to the reserve tranche position of the International Monetary Fund. Another suggestion addresses cross-border local currency payment systems with fine-tuning transactions between national clearing systems and banks.

Key words: BRICS interbank mechanism, BRICS Conditional Currency Reserve Pool, export similarity index, real effective exchange rate, clearing payments, currency swap agreement, escrow account, local currency payments and settlements

Since the second BRICS summit, held in Brasilia on 15 April 2010, monetary cooperation within the BRIC grouping of Brazil, Russia, India and China, later joined by South Africa to form the BRICS, has become a unique form of international economic collaboration to steer bilateral trade and investments toward strong and balanced growth. ${ }^{1}$ While primarily intended to enhance and deepen economic relations, the BRICS partnership has from the beginning also put emphasis on an ambitious segue into the local currency trade settlement arrangements, separately from informal groupings. The first practical document of that summit - the memorandum of understanding between Vnesheconombank (VEB), the China Development Bank (CDB), the Brazilian Development Bank (BNDES) and the Export-Import Bank of India (Exim Bank) - articulated the novelty of the BRICS's multilateral economic cooperation and partnership dialogue. Without a sub-national coordination structure, today it comprises

${ }^{1}$ At the Brasilia Summit, the BRIC leaders declared their intention to "study feasibilities of monetary cooperation, including local currency trade settlement arrangement among our countries" in order to facilitate trade and investment [BRIC, 2010]. 
a range of open and flexible cooperation mechanisms that mature from one BRICS summit to another - in addition to the annual summits and the regular BRICS meetings at the G20 summit, there are working groups, ministers meetings, meetings of heads of financial and tax services, and workshops and forums, and so on. ${ }^{2}$

Since 2010, the BRICS Inter-Bank Cooperation Mechanism and the BRICS Exchanges Alliance have incubated the monetary cooperation among the BRICS countries. The BRICS members gradually set up a specific framework for trade settlement arrangements in order to transform their technical assistance in bilateral projects in the major areas of trade and investment - including in the energy sector between Russia and Brazil, and Brazil and China; in the aircraft industry between China and Brazil; and in the complex equipment manufacturing sector between Russia and China, and between China and South Africa - into an implementation mechanism for economic cooperation [Khmelevskaya, 2012a, p. 145]. The BRICS Exchanges Alliance brought together leading emerging stock markets by cross-listing benchmark equity index derivatives beginning on 30 March 2012. Brazil's IBOVESPA futures, Russia's MICEX Index futures, India's S\&P BSE SENSEX Index futures, Hong Kong's Hang Seng Index futures and Hang Seng China Enterprises Index futures, and South Africa's FTSE/JSE Top40 futures are today known to investors as BRICSMART products. The BRICS Business Council, the BRICS Bank Forum and the BRICS Business Forum were also introduced in 2012-2013 to respond to the possibly wider scope of the BRICS members' interests, and to allow proposals from the financial sector to be studied, discussed and transmitted to the decision-making levels. While many developing countries have significantly extended export growth through deepening trade flows, the BRICS Business Council has suggested that governments streamline the approvals procedure for the establishment of branches and subsidiaries of financial institutions from BRICS countries to promote best banking practices in the key areas of BRICS cooperation including infrastructure, manufacturing and finance [BRICS Business Council, 2014, p. 10].

At the time the BRICS group was formed only Russia and China had joint payments and market infrastructure. ${ }^{3}$ By December 2010 the number of Chinese companies authorized to make cross-border trade payments in renminbi and rubles had grown to 67,000 from 365, 15 Russian banks opened foreign correspondent accounts in renminbi and 10 Russian banks made payments for transactions in renminbi [Khmelevskaya, 2012a, p. 150]. The China Foreign Exchange Trade System [China Foreign Exchange Trade System, 2010] launched direct trading between the renminbi and the ruble in the interbank foreign exchange market on 22 November 2010, and the Moscow exchange followed less than a month later. Since 26 March 2013 China and Brazil extended exchange payments for transactions in renminbi and reais under their bilateral currency swap agreement valued at 190 billion renminbi or 60 billion real. ${ }^{4}$

Accelerating bilateral trade among BRICS countries has inevitably pushed the progress of interbank relationships and their instruments; between 2009 and 2012 trade between Russia and China increased by $32 \%$ per year, and between Brazil and China, Brazil and India, grew $20 \%$ annually. ${ }^{5}$ The first multilateral Master Agreement on Extending Credit Facility in Local Currency and the BRICS Multilateral Letter of Credit Confirmation Facility Agreement were

${ }^{2}$ The BRICS Parliamentary Forum, in Moscow on 8 June 2015, and the BRICS Youth Summit in Kazan on 1-7 July 2015 bring the total of dialogue forums to 25 .

${ }^{3}$ The first agreement on trade and economic relations between Russia and China was signed in 1992 and became the basis for the revised Bilateral Local Currency Settlement Agreement signed on 23 June 2011.

${ }^{4}$ See Resolution 4.200 of the Central Bank of Brazil on 26 March 2013. The Brazilian Monetary Council established the limits and conditions of the bilateral currency swap agreement signed on 27 March 2013 between the Central Bank of Brazil and the People's Bank of China.

${ }^{5}$ Estimated using data from the International Trade Centre (ITC) at http://www.macmap.org. 
signed in New Delhi in 2012. Finally, the BRICS Conditional Currency Reserve Pool and the BRICS New Development Bank (NDB) were launched to turn the limited range of interbank facilities and issues into a full-fledged mechanism of monetary cooperation. The Russian State Duma was the first to ratify the agreements establishing the NDB and the reserve pool, and Vladimir Putin signed them into laws on 9 March and 5 May 2015.

The external shocks that pushed the BRICS to consolidation in 2009 also play a prominent role today in the feasibility of members' monetary cooperation. In April 2013 the Moscow exchange introduced new contracts for spot and swap renminbi/ruble currency pair trading and partial pre-funding of cash, as well as reduced fees for current and new instruments. In October 2014 Russia and China signed their first bilateral currency swap agreement. In April 2015 South Africa and China agreed to make payments in rand and renminbi under bilateral currency swap valued at 30 billion renminbi. ${ }^{6}$ In addition to stimulating business in border regions, joint Chinese and Russian initiatives also address the negative externalities of the non-market nature that are destructive for normal commercial practice and customs.

Most countries turn to these types of currency trade settlement arrangements only in the final stages of economic convergence (European Union); after fine-tuning their banking systems (East Caribbean Currency Union, Trans-European Automated Real-Time Gross Settlement Express Transfer System [TARGET]); within bilateral cross-border local currencies payment systems in the Mercosur such as between Brazil and Argentina, and between Brazil and Uruguay; or in a multilateral clearing scheme such as the Associación Latinoamericana de Integración (ALADI) Reciprocal Payments and Credits Agreement. In seeking a real monetary partnership, the BRICS will inevitably meet numerous challenges, which will in turn mature the group's cooperation and steer it toward stable and balanced growth.

\section{Formal Arrangements for Settling Trade among BRICS Members in Local Currencies}

To ensure the settlement of trade among BRICS in their local currencies a set of pre-conditions need to be met. Potentially, the choice of currency to be used for international payments depends on the market-driven nominal exchange rate for payments and proportions of bilateral trade for settlements. From the point of microeconomic stability, the current account payments and transfers are part of the money supply aggregate liquidity flows. Therefore, while accumulating, for instance, renminbi or rubles to pay for imports the liquidity may expand, which fuels increased demand for apparently stronger currencies. The freer the exchange rates float, the more market expectations rise associated with the so-called "fear of floating" relevant to all BRICS countries except China. Exporters and importers' choice of currency for payments depends mainly on the exchange rate margin as they put in all the transaction costs, but also on other factors including how freely a currency can be used and how volatile the exchange rate. Thus, during 2010 to 2013 the Brazilian real, the Indian rupiah and the South African rand were most volatile currencies of the BRICS countries, and at the end of 2014 it was the Russian ruble.

During the appreciation of the Brazilian real in the second half of 2010 the real effective exchange rate (REER) grew to 3.6\%, and the volume of payments using the cross-border local currencies payment system between Brazil and Argentina (Sistema de Pagos en Moneda Local [SML]) accelerated 2.3 times - resulting in an accumulated volume to the end of the year 2.7 times larger than for the entire previous period. In May 2010, after three months of synchronous

${ }^{6}$ See Media Release of the South African Reserve Bank (SARB) on 4 April 2015. 
devaluation of the Argentina peso and real, three import transactions from Argentina alone represented a five-fold increase in the volume of payments for the previous three months. ${ }^{7}$

As per the obligations under Article VIII and further defined under Article XXX $f$ of the Articles of Agreement of the International Monetary Fund (IMF), all the BRICS currencies are freely usable as they are, in fact, widely used to make payments for international transactions and traded in the principal exchange markets. At Clearstream Banking SA and Euroclear Bank $\mathrm{SA} / \mathrm{NV}$, payment transactions are performed in rubles at the Deutsche Bank in Moscow, in Brazilian reais through accounts open in Itaú DTVM SA, and in South African rand through Standard Chartered Bank in Johannesburg. Non-cash operations with funds in rubles (equities and corporate bonds) are also available for settlement via Euroclear and Clearstream, which link directly to the Moscow Exchange, Russia's Central Security Depository and the National Settlement Depository. The legal right to choose the currency of payment for merchandise export or import has, of course, also significantly strengthened the payments framework.

Russian and Chinese residents can select currency and means of payment in accordance with the 1992 agreement between their two governments on trade and economic relations, which was amended in 2010. In 2014 more than $90 \%$ of cross-border trade payments between Russia and China were settled in rubles with later conversion into renminbi or dollars. The total turnover of correspondent banking between Russia and China has increased by $20-35 \%$ annually [Khmelevskaya, 2012a, pp. 148-49]. Before direct trading between renminbi and ruble, it was a common practice to convert export revenue into other freely usable currencies, predominantly the U.S. dollar and euro. Consequently, the question of which assets will be authorized to allocate money from current accounts arises, and will be vital for national banks and their performance ratios. As most such barriers among the BRICS countries can be attributed to the differences in risk assessments and performance standards, they might need to establish a common rating agency or, at least, harmonize national standards.

To cushion short-term liquidity pressure and to strengthen completely integrated central banks' cross currency swaps, intergovernmental clearing among the BRICS may draw on the BRICS Conditional Currency Reserve Pool (there were also clearing ruble, clearing renminbi and clearing rupiah until 1999 among Russia, China and India), which is technologically very similar to the IMF's self-financing mechanism the reserve tranche position. ${ }^{8}$ The reserve tranche position is a member's liquid claim on the IMF's international reserves, equal to the member's quota minus the IMF's holdings of the member's currency. Hence, the reserve asset paid by a member for its quota subscription creates an equal amount of reserve tranche position, and the IMF lends to other members. By the same logic China may require half its contribution to the BRICS Conditional Currency Reserve Pool, Russia, India and Brazil their full contributions, and South Africa a sum twice as large as their contribution. On the other hand, misalignments of the BRICS currencies caused by global financial instability and negative expectations will be lessened, first, by borrowing-to-contribution ratios and, second, by clearing in the currency of the largest contribution (e.g., China's part is equal to $\$ 41$ billion).

Since 1965 there has been a high value clearing scheme among 12 Latin American states under the ALADI Reciprocal Payments and Credits Agreement (amended 28 April 2014) using the U.S. dollar for cross-rate quotations. In December 2014 the total volume of payments processed exceeded $8 \%$ of intra-regional imports, but the largest decline in its history, more than $40 \%$, was in the second quarter of that same year [ALADI, 2015, p. 5]. During the last decade Argentina and Venezuela have regularly cleared their obligations at the end of the 360 days payment period, thereof, the ALADI is an external financing facility [Khmelevskaya, 2012b, p. 997].

\footnotetext{
${ }^{7}$ Estimated using data from the Central Bank of Brazil at http://www.bcb.gov.br/?estatopercam.

${ }^{8}$ In terms of borrowing allowances and voting power it is similar to the Chiang Mai Initiative.
} 
For BRICS currencies such a multilateral mechanism may create network externalities in international payments systems. For the exchange rate of the renminbi, which is managed against a basket of currencies of its major trading partners, such a mechanism may be a path to integrate into official foreign exchange reserves [Ma and McCauley, 2010; Mattoo, Mishra and Subramanian, 2012]. Questions arise from this point about the parameters of bilateral merchandise trade among BRICS countries and which of them may be targeted for stronger BRICS monetary partnership to respond to the possibly wider scope of BRICS members' interests, and, in their turn, be sensitive enough to currency misalignments and shifts in bilateral trade flows.

\section{The Determinants of Bilateral Trade and Exchange Rates in Local Currency Trade Settlement}

In the modern paradigm of international economic relations, the scale and magnitude of changes and the challenging environment drive the BRICS to turn the tools of political coordination into a full-fledged mechanism for cooperating in trade and investments. Stemming from the BRICS openness, the shifts in sentiment and the volatility in global financial markets, especially in commodity markets, are now introducing external and balance sheet vulnerabilities. Slower growth in China in 2015-2016 is explained by greater weight on vulnerabilities from the recent rapid credit and investment growth, and in India and Brazil by the weaker external demand offset by the boost to the terms of trade from lower oil prices. The IMF's projections for weaker growth in Russia and South Africa also reflect the economic impact of sharply lower oil prices and commodity prices [IMF, 2015, p. 2]. Besides, a pickup in industrial and investment activity after policy reforms in the BRICS is expected to be more than offset by an adjustment to lower medium-term growth in the BRICS countries.

In addition, the "Bigger Brazil Plan" focuses on import substitution in 19 sectors of the domestic economy, and offers tax credits and preferential loans for Brazilian exporters of manufactured goods. Between 2011 and 2014 BNDES spent about \$322 billion in financing the productive sector [Brazilian Development Bank, 2013]. Russia's Industry Development Fund, established to finance the State Industry Development and Competitiveness Enhancement Programme, stimulates the modernization of enterprises and provide import substitution, offering five- to seven-year special purpose loans at 5\% annual interest rate [Government of the Russian Federation, 2014]. Exim India offers assistance to exporter and importers, including their unions such as the Indian Machine Tool Manufacturer's Association, and is a premier finance institution for the "Make in India" and the "Skilling India" programmes. Moreover, Exim India offers information and support through its Export Advisory Service Group (EAS).

Trade within the BRICS mirrors the economic discrepancies and structural differences among the five countries themselves through the universal parameter of transaction costs. It could become the engine of their trade and investment insofar as it lessens transaction costs. At 53.5\%, more than half of aggregate bilateral exports (more than \$296 billion to the end of 2014) come from China. ${ }^{9}$ Starting from a high base, China's volume of trade globally and with its BRICS partners has grown briskly over the past decade.

While the other BRICS members share economic growth and global confidence, their export priorities are reproduced in the bilateral trade flows - since 2012 there has been a marked shift in China's role as a strategic export destination. China has become the major trade partner for Brazil and South Africa, and the second export market and primary import market for In-

${ }^{9}$ Estimated using ITC data at http://www.macmap.org. 
dia. In sum, about one third of Brazilian, Indian and South African trade turnover now arises from economic relationships with China; for Russia it is about $11 \%$ (18\% of imports and $8 \%$ of exports)..$^{10}$

From a geopolitical point of view, such trade proportions among the group of countries with ambitions to coordinate political positions and economic issues is associated both with specific benefits and encumbrances in the form of inter-country trade imbalances [Khmelevskaya, 2015]. Every third foreign trade transaction within the BRICS today is with Chinese partners, which is also a result of China's trade facilitation (tariff rates, costs of trade procedures and formalities, etc.) and competitive advantage. Like other developing countries to some extent, BRICS countries have extended export growth through improvements of their performance at the intensive margin - the expansion and deepening of export relations [Besedes and Prusia, 2007]. In Brazil 27\% of the export growth during the past decade is estimated to come from the extensive margins; the figures for India and China are $22 \%$ and $21 \%$, respectively, and only $6 \%$ for Russia. Over the same period, Brazil has extensively expanded exports of raw minerals (23.9\% growth) and mechanical engineering (13.4\%), while India and Russia increased exports of engineering products, and China expanded in almost all the significant BRICS commodity groups [Gnidchenko, 2014, pp. 48-51].

With regard to the trade structure among the BRICS countries, a consensus has recently emerged that the structure of exports or their diversification is crucial for productivity to achieve economic growth, and that the more open economies with lower barriers have experienced higher growth [McMillan and Rodrik, 2011; Dabla-Norris, Ho, Kochhar et al., p. 25]. The BRICS Business Council [2014, p. 34] has identified tariff and non-tariff barriers as one of the three major barriers and bottlenecks to promoting trade, investment and manufacturing ties among the BRICS countries.

Despite progress during the recent decade, currency deviations rather than tariff barriers persisted in many BRICS countries from 2012 to 2014. The Indian rupiah has been devaluated to support export-oriented growth and lessen trade deficits. Responding to weaker external demand offset by lower commodity prices, Brazil weakened its currency to make its economy more competitive in the global marketplace - a $15 \%$ depreciation between the end of June to the end of 2013. Following the same logic, the Bank of Russia announced a free-floating currency regime in December 2014; with an almost simultaneous drop in world energy prices the ruble depreciated $69 \%$ within two months. ${ }^{11}$ At the same time, Brazil's trade balance surplus with its BRICS partners has remained remarkably consistent during that period - even in 2014 when there was a deficit in total foreign trade for the first time in 14 years, BRICS trade ran a surplus of $\$ 3$ billion (or $3.2 \%$ of aggregate trade with BRICS countries).

In contrast, although the People's Bank of China keeps the value of the renminbi higher in relation to the other BRICS currencies, China's trade deficit is 2.4 times larger than the deficits of the other members together.

To examine the trade structure among BRICS members, the following calculations regarding the Export Similarity Index (ESI) have been used:

$$
S(a b, c)=\left\{\sum i \text { Minimum }[X i(a c), X i(b c)]\right\} 100,
$$

where $X_{\mathrm{i}}(a c)$ and $X_{\mathrm{i}}(b c)$ are industry $i$ 's export shares in country $c$ and country $a$ 's and country $b$ 's exports to country $c$, which in this case includes a group of countries, namely the BRICS.

${ }^{10}$ Estimated using ITC data at http://www.macmap.org.

${ }^{11}$ Estimated using data from the Central Bank of Brazil at http://www.bcb.gov.br and the Moscow exchange at http://www.moex.com. 
The similarity of the BRICS members' export structures is surprisingly low (by the overall ESI among the five countries at two digits) addressing competitive pressure and meaning that large differences still remain in their export structures. All BRICS members have traditionally competed with each other in ore, slag and ash (group 26 at the two-digit level of the harmonized system), ${ }^{12}$ mineral fuel (27) organic chemicals (29), iron and steel (72), and machinery, nuclear reactors, boilers, etc. (84). Brazil competes mostly with South Africa in ore, slag and ash, with export structure continuing to be similar at $40 \%$, and Russia competes with South Africa in mineral fuel - at $20 \%$ similarity. At the two-digit level of the harmonized system, South Africa has the highest coefficients (the average overall ESI is $35 \%$, maximum was $60 \%$ with Brazil in 2011 (see Figure 1).

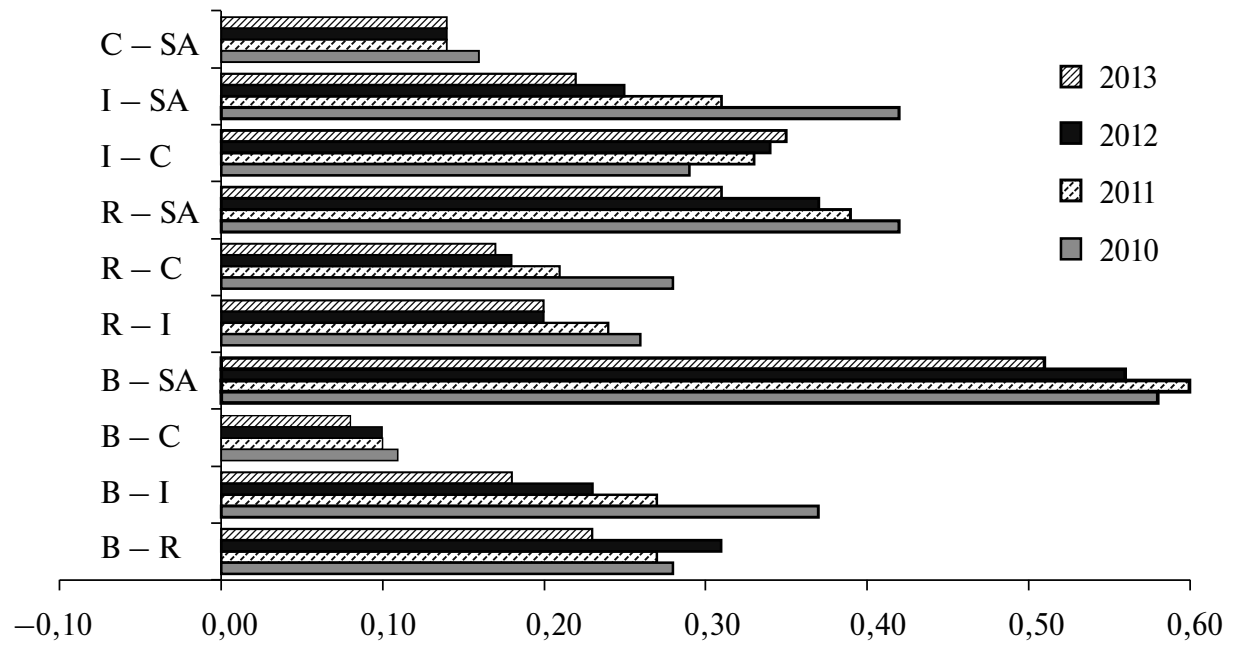

Figure 1: BRICS Export Structures in 2010-2013

Notes: Taken from the Export Similarity Index. B = Brazil, $\mathrm{R}=$ Russia, I $=$ India, $\mathrm{C}=$ China, $\mathrm{SA}=$ South Africa.

With the exception of group 26, decreasing export similarity between BRICS countries is found in all the groups enumerated here that could reflect increased complementarity, as well as their low export positions as far as their separate numbers of commodities and goods are concerned. That corresponds with the shares of BRICS countries' export markets - since 2010 $7 \%$ of China's exports stayed within the BRICS, 7-9\% of Russia's exports, 9-12\% of India's, 15-18\% of South Africa's; from 2009 to 2013 the BRICS market received 18-22\% of Brazil's exports. ${ }^{13}$

Brazil, Russia and China compete with each other and with other countries in machinery, nuclear reactors and boilers (84), as well as in electrical machinery and equipment (85). At the same time the overall ESI still remains low - maximum was 5\% between Russia and China in 2010 - that could reflect a shift in technology content, taking into account the countries' increasing shares of export markets for these goods. Until the end of 2014 Brazil accounted for $40 \%$ of electrical machinery exported from the BRICS, Russia for $37 \%$ and China for $23 \% .{ }^{14}$ Chinese high-technology exports increased by close to 30 percentage points from the mid 1990s

\footnotetext{
${ }^{12}$ Products are listed according to the 2002 Harmonized Commodity Description and Coding System.

${ }^{13}$ Estimated using ITC data at http://www.macmap.org.

${ }^{14}$ Estimated using ITC data at http://www.macmap.org.
} 
to the mid 2000s [IMF, 2011a, p. 18]. Changes in the technology composition of China's exports confirm its rise in BRICS trade in high-tech products (see Table 1).

Table 1. Trade between China and the BRICS (as of December 2013)

\begin{tabular}{|c|c|c|c|c|}
\hline & \multicolumn{4}{|c|}{ China } \\
\hline & \multicolumn{2}{|l|}{ Export } & \multicolumn{2}{|l|}{ Import } \\
\hline & Harmonized System & $\%$ & Harmonized System & $\%$ \\
\hline Brazil & $12,26,27$ & 82 & $\begin{array}{c}85,84,29,87,73,39,72,62,90 \\
54,95,40,61,31,94\end{array}$ & 80 \\
\hline Russia & 27,44 & 77 & $\begin{array}{c}85,84,64,87,62,39,95,61,73 \\
94,90,42,29,40\end{array}$ & 76 \\
\hline India & $\begin{array}{c}52,74,26,29,27,25,39,84 \\
72,15\end{array}$ & 79 & $\begin{array}{c}85,84,29,99,31,73,39,90,72 \\
87,71,89,28\end{array}$ & 79 \\
\hline South Africa & $26,72,27$ & 76 & $\begin{array}{c}85,84,64,61,62,73,39,94,87 \\
72,29,95,40,90\end{array}$ & 76 \\
\hline
\end{tabular}

Notes: Products codes are taken from the 2002 Harmonized Commodity Description and Coding System are according their weight in bilateral export (import).

Although Chinese companies buy mineral fuel (27) from all the other BRICS countries and buy ore, slag and ash (26) from Brazil, India and South Africa, the cumulative volume is still statistically insignificant for China's total imports. In contrast, about half the machinery, nuclear reactors, boilers (84) and electrical and electronic equipment (85) imported by BRICS countries bilaterally is made in China.

On 18 September 2014 the chairs of Indian Railways and China Railway Corporation signed a memorandum of understanding for a joint pre-feasibility study into constructing a high-speed line. According to the agreement, China Rail Eryuan Engineering Group, a subsidiary of the China Railway Corporation, will also assist Indian Railways with its plans to ramp up passenger train speeds from 130 kilometres/hour to 160 kilometres/hour [Thakur, 2014]. Simultaneously the Brazilian group Camargo Corrêa signed a partnership with China Railway Construction Corporation, providing the potential to attract capital for projects to be auctioned in Brazil. In July 2014, Russian Railways International and the Brazilian engineering company Progen signed a deal to jointly participate in Brazil's upcoming railroad concessions [Bland, 2014].

Brazil's exports to China consist mainly of two commodity groups - oil seed, oleagic fruits, grain, seed, fruit, etc. (12) and ore, slag and ash (26), with these groups accounting for more than $72 \%$ of exports (see Table 1). Russia's export of mineral fuel to China has been enlarged from $45 \%$ in 2009 to $74 \%$ in 2014 . India exports predominantly primary products to China; the overall share of four commodities - ore, slag and ash (26), organic chemicals (29), cotton (52), and, copper and copper-based articles (74) - is 58\%. Manufactured products from China dominate imports to the BRICS, specifically groups 84, 85 and 99 (see Table 1). Thus the benefits for the BRICS trading partners depend, first, on China's role in vertical trade integration, which has fuelled China's rise as a leading exporter and, second, on China as a growing source of demand for BRICS economies.

Given the rising Chinese import content in BRICS exports, aggregate trade data are increasingly affected by the flows of intermediate goods that cross borders several times. For instance, in 2013 India imported about half of its electrical and electronic equipment (85) from 
China, of which every third item or chemical originated from China. To some extent, natural silk products, certain toys and sports garments might be originally Chinese made $-97 \%$ of the silk imported by India is Chinese silk. Today, however, there are Chinese components in about $60 \%$ of the product lines in the Indian import, exceeding $30 \%$.

The competitiveness of countries with a large share of foreign value added in their exports has been eroded by the increasing cost of imported production [Bayoumi, Saito and Turunen, 2013, p. 16]. At the same time, although China has become a growing source of demand for other economies, its demand for investment goods has risen more sharply than its demand for consumer goods, particularly, in exposed to its investment demand economies [International Monetary Fund, 2012, pp. 40-41]. Likewise, the more import components intermediate goods contain the larger exchange rate fluctuations might impact negatively on their export [Bayoumi et al., 2013, p. 16].

However, the $30 \%$ appreciation of China's real exchange rate vis-à-vis the U.S. dollar between 2000 and 2008 was associated with an approximately 4.5-6\% increase in the typical developing country's exports to the United States, with much greater effects for countries in closer competition with China [Mattoo, Mishra and Subramanian, 2012, p. 18]. That may have effects for the BRICS, in so far as depreciation of the renminbi increases their exports of raw materials and intermediate goods to China to be used in the production of China's exports. From another perspective, if China's depreciation boosts its own growth, that could increase its demand for all goods and services, which could also lead to greater developing country exports.

Exchange rate discrepancies are defined here as deviations between the real effective exchange rate (REER) and the nominal exchange rate (NER), assuming the REER to be closer to its equilibrium level. Insofar as the effects of exchange rate movements on exports may be significant, one country's policy can then potentially have substantial implications for the exports of other countries. If exchange rate movements stem from their coordinated policy actions, these findings are relevant to the monetary cooperation arrangements developing among the BRICS countries and to the emerging multilateral system.

For these purposes, the REER for BRICS currencies vis-à-vis each other is defined using the following formula:

$$
R E E R^{*}=100 * \Pi_{\mathrm{i}}\left(S_{i^{*}}\left(P^{d} / P^{f}\right)\right)^{\mathrm{w}},
$$

where $w_{i}$ is $i$ 's country share in the BRICS group's trade turnover, normalized with $i$ 's country share in previous year; $P$ is the consumer price index in countries $d$ and $f$; and $S_{i}$ is the NER. Note: the $\log$ version of REER has been used in the calculations.

The ADF test (Dickey-Fuller test) for a unit root claims that the variable is non-stationary as the level of the series is a significant predictor of the next period's change, and has a negative coefficient due to the differences in prices.

The exchange rate discrepancies among the BRICS countries articulate differences in macroeconomic policy (margins between REER and the nominal effective exchange rate [NEER]), and, hence, price preferences for national producers. The real appreciated after 2000 under an inflation-targeting regime, and has been overvalued against the BRICS currencies in the marketplace. The margin between the REER and NER is significant (see Table 2). Externally driven expectations have fuelled the real's purchasing power bias toward the inflation process. Basic products surpassed manufactured goods in Brazilian exports [Nassif, Feijó and Araújo, 2013, pp. 22-23]. However, the strong renminbi with its de facto fixed exchange rate has been undervalued vis-à-vis BRICS currencies other than the Brazilian real (see Table 2). 


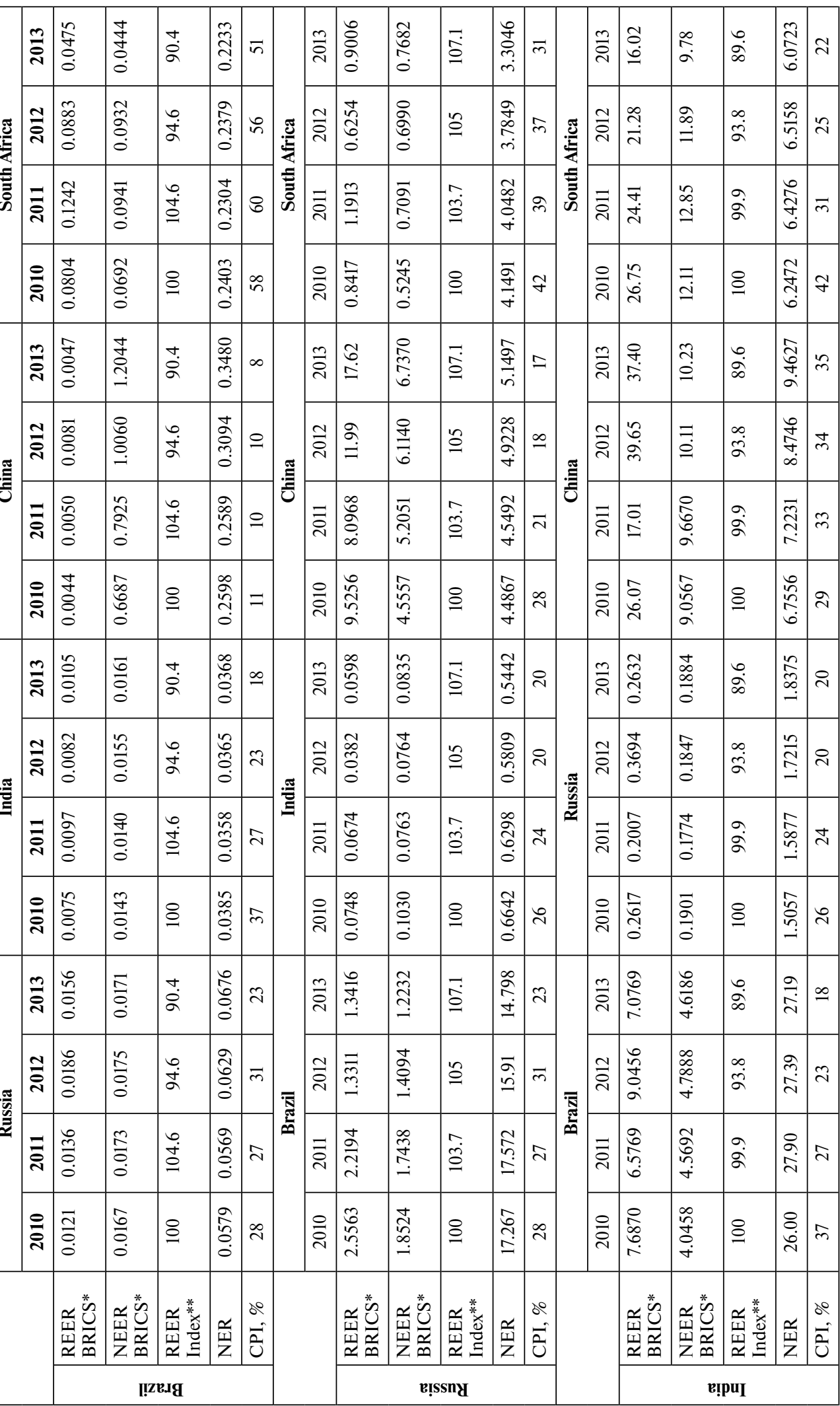




\begin{tabular}{|c|c|c|c|c|c|c|c|c|c|c|c|c|c|c|c|c|}
\hline & $\stackrel{m}{\bar{\sim}}$ & & 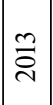 & 离 & 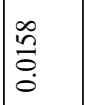 & $\stackrel{a}{=}$ & 竎 & \pm & & $\stackrel{m}{\stackrel{2}{\vec{i}}}$ & 宇. & $\begin{array}{l}\infty \\
\dot{0} \\
\varrho\end{array}$ & $\underset{\infty}{\stackrel{j}{i}}$ & $\mid \begin{array}{l}\infty \\
\infty \\
n \\
n \\
\end{array}$ & $\Xi$ & $\begin{array}{l}\frac{\pi}{0} \\
\stackrel{0}{0} \\
\frac{4}{0}\end{array}$ \\
\hline 疍 & בิ) & 苞 & ฉี & . & : & $\begin{array}{l}0 \\
\dot{\infty} \\
\stackrel{0}{0}\end{array}$ & $\begin{array}{l}2 \\
0 \\
0 \\
0\end{array}$ & \pm & 茎 & 离 & $\stackrel{n}{\stackrel{n}{m}}$ & $\begin{array}{l}\stackrel{n}{m} \\
\dot{\Xi} \\
\dot{y}\end{array}$ & ָ̇i & $\mid$ & \pm & $\begin{array}{l}\frac{\pi}{\pi} \\
\text { n } \\
n \\
2\end{array}$ \\
\hline 言 & $\overline{\vec{c}}$ & 言 & $\overline{\vec{े}}$ & $\underset{⿱}{\stackrel{8}{0}}$ & $\stackrel{m}{\tilde{a}}$ & $\stackrel{n}{a}$ & $\mid \begin{array}{l}\stackrel{a}{2} \\
\infty \\
\infty \\
0 \\
0\end{array}$ & \pm & E & $\overrightarrow{\vec{i}}$ & $\stackrel{n}{=}$ & I & $\infty$ & 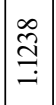 & \pm & $\begin{array}{l}\stackrel{\Xi}{\Xi} \\
0 \\
0\end{array}$ \\
\hline & 을 & & 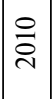 & 点 & 商 & 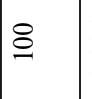 & 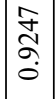 & 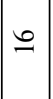 & & $\stackrel{\circ}{\stackrel{2}{2}}$ & $\begin{array}{l}\tilde{N} \\
\ddot{n}\end{array}$ & $\stackrel{n}{9}$ & 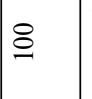 & $\mid \begin{array}{l}\stackrel{0}{\infty} \\
\stackrel{0}{0} \\
\stackrel{-}{-}\end{array}$ & $\mathscr{0}$ & $\stackrel{5}{\frac{5}{3}}$ \\
\hline & 离 & & $\stackrel{m}{\stackrel{\sim}{\grave{2}}}$ & 㝘 & 容 & $\stackrel{a}{\varrho}$ & $\frac{\pi}{\hat{c}}$ & $\approx$ & & $\stackrel{m}{\stackrel{\sim}{\grave{2}}}$ & 暠 & 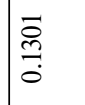 & $\underset{\infty}{\stackrel{\infty}{d}}$ & $\mid \begin{array}{c}\hat{f} \\
\stackrel{f}{0} \\
0\end{array}$ & $\approx$ & ఏ్ \\
\hline 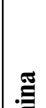 & 곡 & | & $\stackrel{\sim}{\stackrel{\sim}{\sim}}$ & 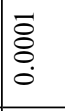 & 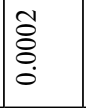 & $\begin{array}{l}0 \\
\infty \\
0\end{array}$ & $\underset{0}{\stackrel{\infty}{*}}$ & $\ddot{m}$ & 舀 & 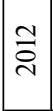 & $\begin{array}{l}0 \\
\infty \\
\infty \\
0 \\
0\end{array}$ & 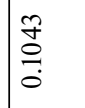 & 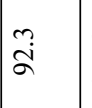 & $\left|\begin{array}{l}n \\
\tilde{n} \\
\\
0\end{array}\right|$ & 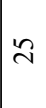 & $\frac{n}{0}$ \\
\hline & $\overline{\mathrm{N}}$ & $\Xi$ & $\overline{\vec{\Xi}}$ & 容 & 答 & 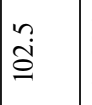 & $\mid \begin{array}{l}0 \\
\infty \\
0 \\
0 \\
0\end{array}$ & $\tilde{m}$ & $\Xi$ & $\bar{\Xi}$ & \begin{tabular}{l}
+ \\
\multirow{2}{*}{} \\
0 \\
0 \\
0
\end{tabular} & 命 & $\infty$ & $\mid \begin{array}{l}0 \\
2 \\
n \\
0 \\
0\end{array}$ & $\bar{m}$ & 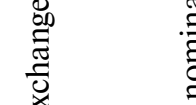 \\
\hline & $\stackrel{\ominus}{\overline{2}}$ & & $\stackrel{\circ}{\stackrel{\sim}{\sim}}$ & 㝘 & 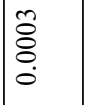 & @ & 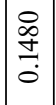 & নे & & $\stackrel{\circ}{\stackrel{\sim}{े}}$ & 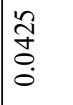 & 导 & 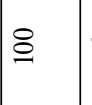 & 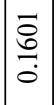 & F & 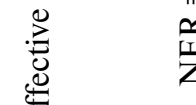 \\
\hline & $\stackrel{m}{\stackrel{2}{2}}$ & & $\stackrel{m}{\stackrel{\sim}{\sim}}$ & $\frac{\infty}{\infty}$ & 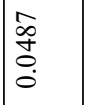 & $\stackrel{\vartheta}{=}$ & $\mid \begin{array}{l}2 \\
\frac{1}{0} \\
0\end{array}$ & $=$ & & $\stackrel{m}{\stackrel{\sim}{\vec{\tau}}}$ & $\stackrel{\substack{0 \\
0}}{0}$ & 荾 & $\underset{\infty}{\stackrel{d}{\infty}}$ & 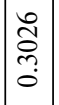 & $\vec{m}$ & $\overparen{\overparen{D}}$ \\
\hline 受 & ั. & . & ฉิ & 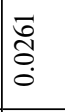 & 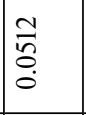 & $\mid \begin{array}{l}0 \\
0 \\
0\end{array}$ & $\begin{array}{c}\overrightarrow{\tilde{O}} \\
\tilde{0}\end{array}$ & $\infty$ & . & $\stackrel{\Xi}{\stackrel{\sim}{\sim}}$ & $\underset{8}{\stackrel{F}{0}}$ & 莒 & 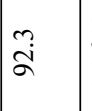 & 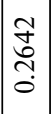 & $\hat{n}$ & $\underset{\omega}{\pi}$ \\
\hline & בิ่ & $\bar{\approx}$ & $\overrightarrow{\vec{\sim}}$ & $\frac{\tilde{a}}{\tilde{\sigma}}$ & $\mid \begin{array}{l}0 \\
0 \\
0 \\
0 \\
0 \\
0\end{array}$ & $\stackrel{n}{\mathfrak{S}}$ & $\mid \begin{array}{l}\infty \\
\stackrel{2}{2} \\
\tilde{0} \\
0\end{array}$ & $\vec{\sim}$ & $\approx$ & $\overrightarrow{\vec{\sim}}$ & 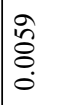 & 离 & $\infty$ & 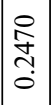 & ले & $\begin{array}{l}\overline{0} \\
\bar{\Xi}\end{array}$ \\
\hline & 产 & & 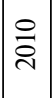 & $\begin{array}{l}\tilde{O} \\
\overparen{\delta} \\
0 \\
0\end{array}$ & 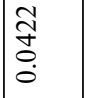 & 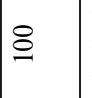 & 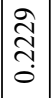 & $\stackrel{\infty}{\sim}$ & & 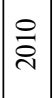 & 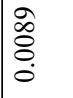 & 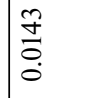 & 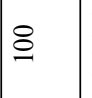 & 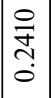 & $\stackrel{\sim}{\mathscr{F}}$ & $\dot{\infty}$ \\
\hline & लm & & $\stackrel{m}{\stackrel{2}{\vec{\nu}}}$ & 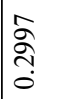 & 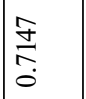 & $\stackrel{a}{=}$ & $\mid$ & $\infty$ & & $\stackrel{m}{\stackrel{\sim}{े}}$ & 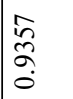 & 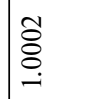 & $\underset{\infty}{\stackrel{i}{d}}$ & 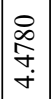 & $\bar{n}$ & 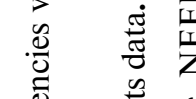 \\
\hline$\frac{\pi}{v_{0}}$ & 고ำ & $\overline{\bar{\pi}}$ & $\stackrel{\sim}{\stackrel{\sim}{\sim}}$ & & 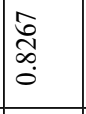 & $\begin{array}{l}0 \\
\infty \\
0 \\
0\end{array}$ & 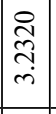 & 으 & $\overline{\mathrm{s}}$ & $\stackrel{\beth}{\stackrel{\sim}{\sim}}$ & 索 & $\mid \begin{array}{l}n \\
\\
\infty \\
0 \\
0\end{array}$ & 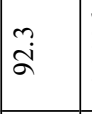 & 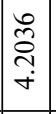 & in & 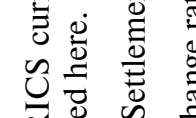 \\
\hline$\approx$ & 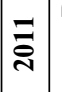 & $\infty$ & $\overrightarrow{\vec{\nabla}}$ & 总 & 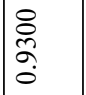 & ڤn & 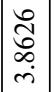 & 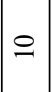 & 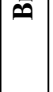 & $\overline{\vec{\sim}}$ & 瓷 & $\frac{\infty}{2}$ & $\propto$ & 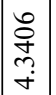 & 8 & 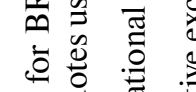 \\
\hline & 올 & & 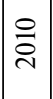 & $\begin{array}{l}\infty \\
\infty \\
n \\
n \\
0 \\
0\end{array}$ & 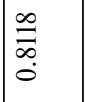 & 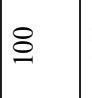 & $\mid$\begin{tabular}{c|}
$\dot{1}$ \\
$\infty$ \\
$\vdots$ \\
$\infty$ \\
$\dot{r}$ \\
$\dot{m}$
\end{tabular} & $=$ & & 음 & 衣 & $\frac{O}{\sigma}$ & 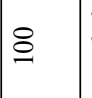 & $\begin{array}{l}0 \\
\stackrel{0}{0} \\
\dot{\sigma}\end{array}$ & $\stackrel{\infty}{i}$ & 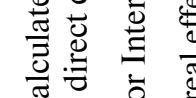 \\
\hline & & & & 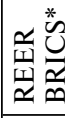 & 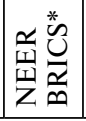 & 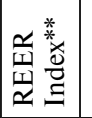 & $\frac{\alpha}{\square}$ & di & & & $\frac{2}{\sqrt[*]{0}}$ & 冚 & 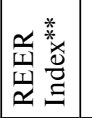 & $\frac{⿱}{4}$ & in & 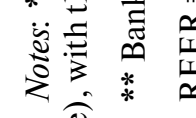 \\
\hline & & & & & Bu! & & & & & & & हอ!ग & ypnos & & & $\mathbb{\Xi}$ \\
\hline
\end{tabular}


The transition to direct trading between the renminbi and the ruble is associated with a wider range of fluctuation of the ruble's market rate and an increase in the purchasing power of the renminbi. Devaluations of some of the BRICS currencies during 2012-2013 have reduced the gap between purchasing power and market-driven exchange rates. For instance, by the end of 2013 the real was 25 basic points (bp) cheaper vis-à-vis the ruble then in 2010-2011, the rand was $16 \mathrm{bp}$ cheaper than the ruble, and the rupiah was only $1 \mathrm{bp}$ down..$^{15}$ In this regard, the further market-driven devaluations of BRICS currencies have been ahead of domestic inflation, the wider the gap between purchasing power and exchange rates, which also reflects also the magnitude of the shifts in sentiment and volatility in global markets from which national producers might sporadically benefit (e.g., Brazilian vis-à-vis South African rand in 2013 and Indian vis-à-vis Russian ruble in 2011).

With regard to the exchange rate discrepancies and BRICS expansion, Brazil and Russia have experienced the highest export growth among the BRICS countries (the common average excluding China is $46 \%$ ). Brazil's export performance was mainly resilient due to the widening and deepening trade relationships among the BRICS countries - components of the intensive margin. With average annual growth of $18 \%$, Brazil's exports to China have doubled, and have increased by 1.3 times to Russia and by 1.4 times to India. Brazil has begun exporting butter and other fats and oils derived from milk to Russia, and its exports of vegetable saps and extracts have seen unprecedented growth - increasing from $\$ 17$ million in 2010 to $\$ 3.5$ billion during 2014. In 2010 Indian consumers tasted the divine aroma of Brazilian chocolate, and the assortment of cotton and chemical fibres also expanded. At the same time, $80 \%$ of Russia's export growth to its BRICS partners consisted of mineral fuels and oil. ${ }^{16}$ As has been pointed out, this means that economic shifts could be reproduced onto export structure changes by participating in global supply chains, which in turn help maintain competitiveness. ESI coefficients for Russia move synchronically with REER, which also indicates a low orientation to BRICS markets - their share of Russia's exports has grown weakly since 2009 at $2 \%$. Hence, the magnitude of the trade response to exchange rate shifts depends on the overall structure of exports.

With respect to the export structure similarity and exchange rate indicators of bilateral trade among the BRICS, estimates have proven that they may serve as determinants of transaction costs as they synchronically catch shifts in trade parameters and exchange rate discrepancies responding to the fundamental trade pattern in which currency appreciation is associated with increasing prices of domestic production factors, and like in China, the export growth and production sharing could help to maintain competitiveness [Mattoo, Mishra and Subramanian, 2012, p. 18]. An examination of the integrated effective exchange rate (IEER), which accounts for changes in the exchange rates of suppliers vis-à-vis the final export market currencies for East Asian economies, has identified that taking Chinese value-added in intermediate inputs into account, the renminbi's IEER has appreciated less than the standard REER since 2008 [IMF, 2011b, p. 53-54].

Transaction costs may thereby be reduced via common trade settlement arrangements and trade facilitation. During the period of extreme ruble volatility in 2014, the Indian government and the Federation of Indian Export Organizations (FIEO) offered to put in place a rupeeruble agreement similar to the one in place with Iran [Basu, 2014]. Indian imports from Russia comprise mainly primary goods (crude oil, precious metals and stones, copper and fertilizers, etc.) and exports consist both of high-technology goods - pharmaceuticals, parts for machinery and aircraft, etc. $-38 \%$ of total exports to Russia, ${ }^{17}$ and such commodities as coffee and tea,

\footnotetext{
${ }^{15}$ Estimated using ITC data at http://www.macmap.org.

${ }^{16}$ Estimated using ITC data at http://www.macmap.org.

${ }^{17}$ Estimated using ITC data at http://www.macmap.org.
} 
iron and steel, and fish. The Indian offer would also revive the escrow account once maintained with the Soviet Union as an alternative to the letter of credit, which banks in both countries can use to accumulate their claims against each other and then settle them in their local currencies [Maurer and Harl, 1992, pp. 5-6]. India and Iran have an agreement that India pays for its crude oil imports in rupees for through the Kolkata-based UCO Bank; previous agreements were with the Europäisch-Iranische Handelsbank in Hamburg and Turkey's Halkbank. For BRICS members the NDB might serve as an escrow agent, as being multilateral allows it to avoid sanctions.

Given that only the ruble and the renminbi are traded directly, to be a part of BRICS safety net the local currency trade settlement framework must contain a clearing mechanism and a payment network. The BRICS already have an institutional platform for a clearing union in the BRICS Conditional Currency Reserve Pool, but will face challenges in interbank communication networks and standards for settlement bank performance. For instance, the China National Advanced Payment System does not use SWIFT MT202/202COV codes for interbank transfers and its bank identification codes (BIC) differ from the other BRICS members.

For the design of a payment network, the BRICS might consider the example of the bilateral cross-border local currency payment systems between Brazil and Argentina (Sistema de Pagos en Moneda Local, SML) and between Brazil and Uruguay, which are based on national clearing and indicative rates that do not require direct currency trading and are therefore independent of the regulations of the central bank of the partner country [Banco Central do Brasil, 2008]. Given that all the BRICS members incorporate universal real-time gross settlement and operated by their central banks in their national payments and clearing systems, technologically it would be easier to fine-tune their operational procedures and time schedules in order to interconnect for transfers in BRICS currencies, as the SML has done. At the same time, in light of the exchange rate discrepancies among the BRICS, a compensation scheme is also required to support liquidity in a local currency trade settlement framework.

\section{References}

Associación Latinoamericana de Integración (2015) Convenio de pagos y créditos recíprocos. 5 February. Montevideo. Available at: http://www.aladi.org/nsfaladi/convenio.nsf/documentos/\$file/TercerCuatri2014. pdf (accessed 25 May 2015).

Banco Central do Brasil (2008) "Convênio do sistema de pagamentos em moeda local entre a República Argentina e a República Federativa do Brasil." ["Agreement of Local Currency Payment System between Argentina and Brazil.”] 8 September. Available at: http://www.bcb.gov.br/rex/sml/convenio-sml-pt.pdf (accessed 25 May 2015).

Basu N. (2014) Government mulls rupee payment deal with Russia. Business Standard, 24 December. Available at: http://www.business-standard.com/article/economy-policy/government-mulls-rupee-payment-dealwith-russia-114122400071_1.html (accessed 25 May 2015).

Bayoumi T., M. Saito and J. Turunen (2013) Measuring competitiveness: trade in goods or tasks? IMF Working Paper, WP/13/100, May. Washington DC: International Monetary Fund. Available at: https://www.imf.org/ external/pubs/ft/wp/2013/wp13100.pdf (accessed 25 May 2015).

Besedes T. and T. J. Prusia (2007) The role of extensive and intensive margins and export growth. NBER Working Paper no. 13628, November. doi: 10.3386/w13628.

Bland D. (2014) "Chinese-Brazilian group ready for rail concession tender.” BNamericas, 21 July. Available at: http://subscriber.bnamericas.com/news/infrastructure/chinese-brazilian-group-ready-for-rail-concessiontender1 (accessed 25 May 2015). 
Brazilian Development Bank (2013) Annual report 2013: deliveries to society. Brasilia. Available at: http:// www.bndes.gov.br/SiteBNDES/export/sites/default/bndes_en/Galerias/RelAnualEnglish/ra2013/Rel_ Anual_2013_ingles.pdf (accessed 31 May 2015).

BRIC (2010) "2nd BRIC summit of heads of state and government: joint statement of the BRIC countries' leaders.” Brasilia, 15 April. Available at: http://www.brics.utoronto.ca/docs/100415-leaders.html (accessed 25 May 2015).

BRICS Business Council (2014) "BRICS Business Council 2013/2014 annual report." 9 July. Available at: http://arquivos.portaldaindustria.com.br/app/conteudo_18/2014/07/15/6862/BRICSBusinessCouncilAnnu alReportDRAFT6-11JulySignature.pdf (accessed 31 May 2015).

China Foreign Exchange Trade System (2010) "Public announcement of China Foreign Exchange Trade System on launching the trading between RMB and ruble in the interbank foreign exchange market." Beijing, 22 November. Available at: http://www.chinamoney.com.cn/fe/Info/2819345 (accessed 25 May 2015).

Dabla-Norris E., G. Ho, K. Kochhar et al. (2013) "Anchoring growth: the importance of productivityenhancing reforms in emerging market and developing economies." Staff discussion note, International Monetary Fund, Washington DC, December. Available at: https://www.imf.org/external/pubs/ft/sdn/2013/ sdn1308.pdf (accessed 25 May 2015).

Gnidchenko A. (2014) Decomposing export growth into extensive and intensive margins with the emphasis on comparative advantages. Journal of the New Economic Association 24(4), pp. 38-64. Available at: http:// EconPapers.repec.org/RePEc:nea:journl:y:2014:i:24:p:38-64 (accessed 25 May 2015).

Government of the Russian Federation (2014) "Decision no. 328 on approval of the state program on 'The development of industry and increased competitiveness'.” Moscow, 15 April. Available at: http://government. ru/media/files/lgqVAlrW8Nw.pdf (accessed 25 May 2015).

International Monetary Fund (2011a) "Changing patterns of global trade." Washington DC, 15 June. Available at: https://www.imf.org/external/np/pp/eng/2011/061511.pdf (accessed 25 May 2015).

International Monetary Fund (2011b) Regionaleconomic outlook: Asia and Pacific. Washington DC: International Monetary Fund. Available at: http://www.imf.org/external/pubs/ft/reo/2011/apd/eng/areo0411.pdf

International Monetary Fund (2012) Regional economic outlook: Asia and Pacific. Washington DC: International Monetary Fund. Available at:http://www.imf.org/external/pubs/ft/reo/2012/APD/eng/c4_0412.pdf (accessed 25 May 2015).

International Monetary Fund (2015) World economic outlook update. 20 January. Washington DC. Available at: http://www.imf.org/external/pubs/ft/weo/2015/update/01/pdf/0115.pdf (accessed 25 May 2015).

Khmelevskaya N. (2012a) BRIKS valyutnyy partnerstvo : predposylki i uprekaya Interesy [BRICS monetary partnership: prerequisites and reproaching interests]. In: BRIKS, Giganty razvivayushchikhsya rynkov: rol'v global'noy politike i natsional'nykh strategiy modernizatsii [The BRICS, giants of emerging markets: role in global policy and national modernization strategies]. Moscow: MGIMO University. pp. 144-57.

Khmelevskaya N. (2012b) La arquitectura financiera subnacional en América Latina: los éxitos para estabilidad económica en la era de globalización. In: A. Colomer Viadel, ed America Latina, Globalidad e Integracion. Madrid: Ediciones del Orto. pp. 993-1000. Available at: http://sistemanodalsinaloa.gob.mx/ archivoscomprobatorios/_12_capitulolibro/333.pdf (accessed 25 May 2015).

Khmelevskaya N. (2015) Trade integration in Mercosur vs infrastructure integration in Pacific alliance. Latin America 2, pp. 48-58.

Ma G. and R. N. McCauley (2010) The evolving renminbi regime and implications for Asian currency stability. Working paper no. 321, September. Basel: Bank for International Settlements. Available at: http://www.bis.org/ publ/work321.htm (accessed 25 May 2015).

Mattoo A., P. Mishra and A. Subramanian (2012) "Spillover effects of exchange rates: a study of the renminbi." IMF Working Paper, WP/12/88, International Monetary Fund, Washington DC, March. Available at: http:// www.imf.org/external/pubs/ft/wp/2012/wp1288.pdf (accessed 25 May 2015).

Maurer M. T. and N.E. Harl (1992) Using excrow accounts and letters of credit to assure payment under credit sales agreements. Journal of Agriculture and Law 14(1), pp. 3-24. 
McMillan M. S. and D. Rodrik (2011) Globalization, structural change and productivity growth. NBER working paper no. 17143, June. doi: 10.3386/w17143.

Nassif A., C. Feijó and E. Araújo (2013) Structural change and economic development: is Brazil catching up or falling behind? Discussion paper no. 211, October. Geneva: United Nations Conference on Trade and Development. Available at: http://unctad.org/en/PublicationsLibrary/osgdp20131_en.pdf (accessed 25 May 2015).

Thakur R. (2014) India and China sign high-speed MoU. International Railway Journal, 22 September. Available at: http://www.railjournal.com/index.php/asia/india-and-china-sign-high-speed-mou.html (accessed 25 May 2015). 